\title{
Purification and characterization of an alkaline isoamylase from an alkalophilic strain of Bacillus
}

\author{
Katsutoshi Ara, ${ }^{*}$ Katsuhisa Saeki and Susumu Ito \\ Tochigi Research Laboratories of Kao Corporation, 2606 Akabane, Ichikai, Haga, Tochigi 321-34, Japan
}

(Received 14 September 1992; revised 25 November 1992; accepted 9 December 1992)

\begin{abstract}
Alkaline isoamylase (glycogen 6-glucanohydrolase, EC 3.2.1.68) activity was detected in the culture medium of an alkalophilic strain of Bacillus sp., designated KSM-3309, which was isolated from a soil sample. This novel enzyme was purified to homogeneity from the culture filtrate by precipitation with ammonium sulphate, chromatography on DEAE-cellulose and DEAE-Bio-Gel A, and gel filtration on Sephacryl S-200. The purified enzyme had a pH optimum of approximately 9.0 , and displayed maximum catalytic activity at $55{ }^{\circ} \mathrm{C}$. The enzyme had a molecular mass of $65 \mathrm{kDa}$, as determined by both SDS-polyacrylamide gel electrophoresis and gel filtration on Sephacryl S-200. The isoelectric point was 4.2. This enzyme cleaved the branching points of both amylopectin and glycogen, and incubation of the enzyme with these glucans caused large increases in coloration of the iodine reagent. Amylose, pullulan and maltose were practically insensitive to the enzyme. The enzyme activity was inhibited by $\mathrm{Hg}^{2+}$ ions and by $\mathrm{N}$-bromosuccinimide, but the thiol inhibitors iodoacetate, 4-chloromercuribenzoate and $\boldsymbol{N}$-ethylmaleimide had either no effect or a slightly inhibitory effect. $\boldsymbol{\beta}$-Cyclodextrin, an inhibitor of pullulanase, was not inhibitory.
\end{abstract}

\section{Introduction}

Unlike $\alpha$-amylase (1,4- $\alpha$-D-glucan 4 -glucanohydrolase, EC 3.2.1.1), isoamylase (glycogen 6-glucanohydrolase, EC 3.2.1.68) and pullulanase (pullulan 6-glucanohydrolase, EC 3.2.1.41) hydrolyse the 1-6- $\alpha$-D-glucosidic inter-chain linkages of certain branched $\alpha$-Dglucans. The enzymes differ mainly in that isoamylase cannot hydrolyse pullulan. Isoamylase was first found in autolysed brewers' yeast (Maruo \& Kobayashi, 1951) and then in bakers' yeast (Gunja et al., 1961). Harada et al. (1968) identified an extracellular isoamylase produced by Pseudomonas amyloderamosa, which was then purified and characterized (Yokobayashi et al., 1970; Harada et al., 1972). Subsequently, several bacteria, such as Cytophaga sp. (Gunja-Smith et al., 1970a), Bacillus amyloliquefaciens (Urlaub \& Wober, 1975), Escherichia coli (Jeanningros et al., 1975). Flavobacterium sp. (Sato \& Park, 1980), and the yeast Lipomyces kononenkoae (Spencer-Martins, 1982) were found to produce isoamylases. These isoamylases, including pullulanases, can potentially be used in the elucidation of the fine structures of polysaccharides and related $\alpha$-glucans (Gunja-Smith et al., 1970b; Akai et al., 1971; Hizukuri et al., 1983) and

\footnotetext{
*Author for correspondence. Tel. 81285837400 ; fax 8128583 7403 .
}

for the industrial production of amylose, maltose and glucose from starch, in combination with other amylolytic enzymes (Norman, 1982; Stominska \& Maczynski, 1985).

Recently, we have found that glycogen- and amylopectin-debranching enzymes, such as pullulanases and isoamylases, can be used as effective additives in dishwashing and laundry detergents (unpublished results), as also reported by us for alkaline endoglucanases from some strains of Bacillus (Okoshi et al., 1990; Yoshimatsu et al., 1990). We have isolated a strain of Bacillus that produces an alkaline pullulanase, the properties of which also fulfil the essential requirements for enzymes to be used for such purposes (Ara et al., 1992). However, isoamylases of microbial origin reported to date cannot be used in alkaline detergents since they all have maximum activities at acidic $\mathrm{pH}$ values. This report describes the production, purification and properties of an alkaline isoamylase from an alkalophilic strain of Bacillus isolated from soil.

\section{Methods}

Organism and culture conditions. The organism used was Bacillus sp. KSM-3309, which was originally isolated from a soil sample collected in Mito, Japan. Its morphological and taxonomic characteristics were examined according to the methods of Gordon et al. (1973) and Claus \& Berkeley (1986). 
Bacillus sp. KSM-3309 was propagated at $30^{\circ} \mathrm{C}$ in a medium composed of $(\mathrm{w} / \mathrm{v}): 1.0 \%$ glycogen (from oyster; Sigma). $0.2 \%$ Tryptone (Difco), $0.1 \%$ yeast extract (Difco), $0.1 \%\left(\mathrm{NH}_{4}\right)_{2} \mathrm{SO}_{4}, 0.3 \%$ $\mathrm{KH}_{2} \mathrm{PO}_{4}, 0.02 \% \mathrm{MgSO}_{4} .7 \mathrm{H}_{2} \mathrm{O}, 0.02 \% \mathrm{CaCl}_{2} .2 \mathrm{H}_{2} \mathrm{O}, 0.001 \% \mathrm{FeSO}_{4}$ $.7 \mathrm{H}_{2} \mathrm{O}, 0.0001 \% \mathrm{MnSO}_{4} .4 \mathrm{H}_{2} \mathrm{O}$ and $0.5 \% \mathrm{Na}_{2} \mathrm{CO}_{3}$ (pH 9.2). Solutions of $\mathrm{CaCl}_{2}$ and $\mathrm{Na}_{2} \mathrm{CO}_{3}$ were autoclaved separately. The organism was grown with shaking at $30^{\circ} \mathrm{C}$ for $3 \mathrm{~d}$ in $100 \mathrm{ml}$ aliquots of medium in $500 \mathrm{ml}$ flasks. Cells were harvested by centrifugation $(9800 \mathrm{~g}, 30 \mathrm{~min})$ at $4{ }^{\circ} \mathrm{C}$. All further manipulations were also done at this temperature. The supernatant obtained was used for purification of the enzyme.

Purification of the enzyme. The supernatant from a 3 litre culture was treated with ammonium sulphate, and the fraction that precipitated at $80 \%$ saturation was collected by centrifugation $(12000 \mathrm{~g}, 20 \mathrm{~min})$. The precipitate was dissolved in $10 \mathrm{mM}$-Tris/ $\mathrm{HCl}$ buffer $(\mathrm{pH} \mathrm{8.0)}$ ) and the solution was dialysed twice over the course of $16 \mathrm{~h}$ against $50 \mathrm{vols}$ of the same buffer. The retentate was diluted to $100 \mathrm{ml}$ with $10 \mathrm{mM}$ Tris/ $\mathrm{HCl}$ (pH 8.5) and mixed with DE52-cellulose powder (1 g; Whatman) that had been equilibrated in the same buffer. After the suspension had been mixed gently for $30 \mathrm{~min}$, the support was collected on a membrane (PM-10, 100000- $M_{\mathrm{r}}$ cutoff; Amicon) and washed with $10 \mathrm{~mm}$-Tris $/ \mathrm{HCl}$ buffer. Proteins were then eluted with the same buffer supplemented with $1.0 \mathrm{M}-\mathrm{NaCl}$. The eluate obtained was concentrated by ultrafiltration (PM-10) and directly applied to a column of DEAEBio-Gel A $(1.5 \mathrm{~cm} \times 60 \mathrm{~cm}$; Bio-Rad) that had been equilibrated with $10 \mathrm{~mm}$-Tris/HCl buffer ( $\mathrm{pH} \mathrm{8.0)}$. The column was first washed with $300 \mathrm{ml}$ of the equilibrating buffer and proteins were eluted with a $1 \cdot 0$ litre linear gradient of 0 to $1.0 \mathrm{M}-\mathrm{NaCl}$ in the same buffer, at a flow rate of $40 \mathrm{ml} \mathrm{h}^{-1}$. Fractions of $1.5 \mathrm{ml}$ were collected from the start of the gradient. The active fractions (tubes 272-283) were combined and concentrated by ultrafiltration on a PM-10 membrane. The concentrate $(1 \mathrm{ml})$ was loaded directly on a column of Sephacryl S-200 $(1.5 \mathrm{~cm} \times$ $96 \mathrm{~cm}$; Pharmacia) that had been equilibrated with $10 \mathrm{~mm}-\mathrm{Tris} / \mathrm{HCl}$ buffer $(\mathrm{pH} \mathrm{8.0)}$ containing $0.1 \mathrm{M}-\mathrm{NaCl}$. Elution was done with the same buffer; $1.5 \mathrm{ml}$ fractions were collected at a flow rate of $7 \mathrm{ml} \mathrm{h}^{-1}$. The elution pattern was monitored by measuring protein (absorbance at $280 \mathrm{~nm}$ ) and isoamylase activity in each fraction. Only one peak of isoamylase activity (fractions 57-62) was eluted. The active fractions were combined and dialysed overnight against a large volume of $10 \mathrm{~mm}$-Tris/ $\mathrm{HCl}$ buffer (pH 8.0), and the retentate was used for further experiments as the final preparation of purified enzyme.

Enzyme assay. The routine assay for isoamylase activity using oyster glycogen as substrate was performed with $50 \mathrm{mg}$ substrate and a sample of enzyme in $1.0 \mathrm{ml} 40 \mathrm{~mm}$-glycine $/ \mathrm{NaCl} / \mathrm{NaOH}$ buffer $\left(\mathrm{pH} \mathrm{9.0)}\right.$; reactions were incubated at $40^{\circ} \mathrm{C}$ for $15 \mathrm{~min}$. The reducing sugar formed was quantified as glucose by the dinitrosalicylic acid procedure (Miller et al., 1960). One unit (U) of enzyme activity was defined as the amount of protein that produced $1 \mu \mathrm{mol}$ product $\mathrm{min}^{-1}$ under these conditions. Isoamylase activity was also followed with amylopectin as substrate, by determining the increase in iodine staining power (Maruo \& Kobayashi, 1951). The reaction mixture consisted of $0.5 \mathrm{ml} 2.0 \%(\mathrm{w} / \mathrm{v})$ potato amylopectin (Sigma) in $0.2 \mathrm{M}$-glycine/ $\mathrm{NaCl} / \mathrm{NaOH}$ buffer (pH 9.0) and $0.5 \mathrm{ml}$ enzyme solution. At intervals, $0.2 \mathrm{ml}$ aliquots of the reaction mixture were mixed with $2.0 \mathrm{ml}$ aliquots of iodine solution $\left(0.005 \% \mathrm{I}_{2}\right.$ plus $\left.0.015 \% \mathrm{KI}\right)$, and each mixture was diluted to $8.0 \mathrm{ml}$ with deionized water. One unit of isoamylase activity was defined as the amount of protein that caused an increase in absorbance at $600 \mathrm{~nm}$ of $0.01 \mathrm{~min}^{-1}$ under the standard assay conditions. Protein was quantified by the procedure of Bradford (1976) using the Bio-Rad protein assay kit, with bovine serum albumin as the standard.

Electrophoresis. Polyacrylamide gel electrophoresis (PAGE) and sodium dodecyl sulphate (SDS)-PAGE were done using $7.5 \%(\mathrm{w} / \mathrm{v})$ and $15 \%$ acrylamide slab gels, respectively, as described elsewhere (Ara et al., 1992). Isoelectric focusing of the purified enzyme was done by
PAGE, as described by Wrigley (1971). The enzyme (10 $\mu \mathrm{g})$ was subjected to electrophoresis on a column $(0.5 \mathrm{~cm} \times 8.5 \mathrm{~cm})$ of $7.5 \%$ acrylamide gel that contained $13.3 \%(\mathrm{v} / \mathrm{v})$ glycerol and $1.9 \%(\mathrm{v} / \mathrm{v})$ Pharmalyte ( $\mathrm{pH}$ range $3-10$; Pharmacia), at a constant voltage of $300 \mathrm{~V}$ for $14 \mathrm{~h}$ at $4{ }^{\circ} \mathrm{C}$, with the cathode in the upper chamber $(20 \mathrm{~mm}$ $\left.\mathrm{H}_{3} \mathrm{PO}_{4}\right)$ and the anode in the lower one $(0 \cdot 1 \mathrm{M}-\mathrm{NaOH})$. The isoelectric point was determined by cutting out zones of gel, soaking them in deionized water and measuring the $\mathrm{pH}$ of the resultant solution.

Determination of molecular mass. Molecular mass was estimated both by gel filtration on a column of Sephacryl S-200 and by SDSPAGE. The Sephacryl column $(1.5 \mathrm{~cm} \times 96 \mathrm{~cm})$ was equilibrated with $10 \mathrm{~mm}$-Tris/ $\mathrm{HCl}$ buffer ( $\mathrm{pH} \mathrm{8.0)}$ supplemented with $0.1 \mathrm{M}-\mathrm{NaCl}$ and calibrated by elution of molecular-mass markers (Pharmacia), which included hen egg white ovalbumin $(42.7 \mathrm{kDa})$, bovine serum albumin $(66.2 \mathrm{kDa})$, rabbit muscle phosphorylase $b(97.4 \mathrm{kDa})$, rabbit muscle aldolase $(158 \mathrm{kDa})$, bovine liver catalase $(232 \mathrm{kDa})$ and horse spleen ferritin $(440 \mathrm{kDa})$. For the determination of molecular mass by SDSPAGE, molecular mass markers for SDS-PAGE (Bio-Rad) were used: soybean trypsin inhibitor $(21.5 \mathrm{kDa})$, bovine carbonic anhydrase (31 kDa), hen egg white ovalbumin $(42.7 \mathrm{kDa})$, bovine serum albumin $(66.2 \mathrm{kDa})$ and rabbit muscle phosphorylase $b(97.4 \mathrm{kDa})$.

Chromatographic analysis of the products of hydrolysis of polysaccharides. Excess purified enzyme $(15 \mathrm{mU})$ was incubated at $40^{\circ} \mathrm{C}$ for an appropriate length of time (up to $12 \mathrm{~h}$ ) in $2.0 \mathrm{ml}$ of $40 \mathrm{mM}$-Tris/ $\mathrm{HCl}$ buffer ( $\mathrm{pH} \mathrm{8.0)}$ ) with $0.5 \mathrm{mg}$ of the following polysaccharides: pullulan (Hayashibara), potato amylose (DP $=17$; Wako Pure Chemical), corn amylopectin (Sigma), potato amylopectin, oyster glycogen, bovine muscle glycogen (Sigma), or rabbit liver glycogen (Sigma). At intervals, $10 \mu \mathrm{l}$ aliquots were taken and used for ascending paper chromatography (on no. 50 filter paper; Toyo Roshi) in a solvent system of 1butanol/pyridine/water ( $6: 4: 3$, by vol.). The chromatograms were developed by spraying with silver nitrate reagent (Trevelyan et al., 1950).

\section{Results}

\section{Taxonomic characterization of strain KSM-3309}

The isolate grew well at an initial $\mathrm{pH}$ between 8.5 and 10.5 (pH adjusted with $\mathrm{Na}_{2} \mathrm{CO}_{3}$ ) but could not grow below $\mathrm{pH} 8.0$ in nutrient broth containing $1.0 \%(\mathrm{w} / \mathrm{v})$ glucose, i.e. it was an obligate alkalophile. Therefore, media used for identification were supplemented with $0.5 \%(\mathrm{w} / \mathrm{v}) \mathrm{Na}_{2} \mathrm{CO}_{3}$. The organism was an obligate aerobe, which was spore-forming (cylindrical, central endospores), Gram-positive, motile, and rod-shaped $(0.8-1.0 \mu \mathrm{m} \times 2.0-2.5 \mu \mathrm{m})$ with peritrichous flagella. It was positive for reduction of nitrate, production of catalase and hydrolysis of starch, and negative for formation of acetoin (V-P test), production of urease and oxidase, and formation of $\mathrm{H}_{2} \mathrm{~S}$ and indole. It seems likely that strain KSM-3309 is a relative of Bacillus circulans.

\section{Purification of the enzyme}

When Bacillus sp. KSM-3309 was grown in medium containing $1.0 \%(\mathrm{w} / \mathrm{v})$ oyster glycogen, isoamylase activity, determined by the iodine staining procedure, 


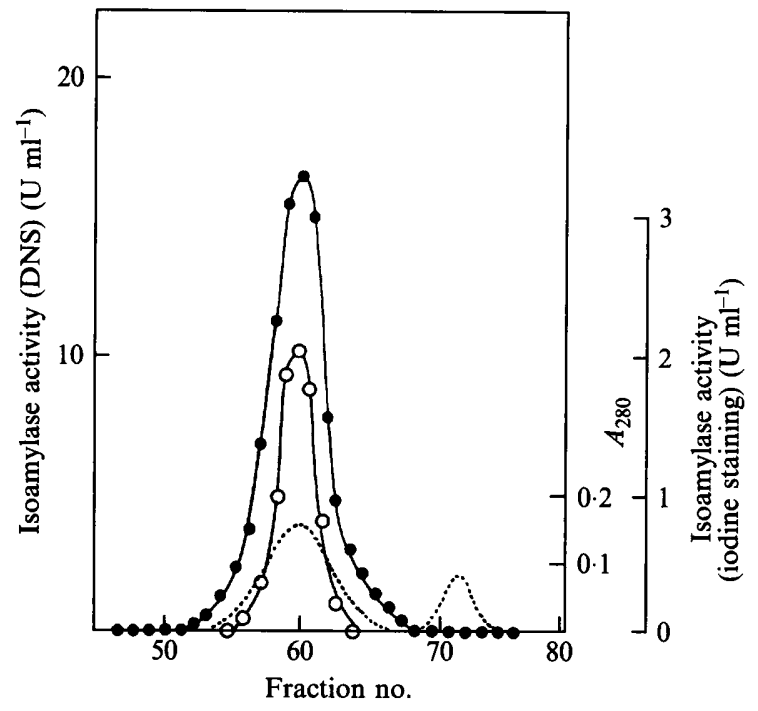

Fig. 1. Gel chromatography of isoamylase on the final column of Sephacryl S-200. Isoamylase activity in each $1.5 \mathrm{ml}$ fraction was measured by both the dinitrosalicylic acid (DNS) (O) and iodine staining $(O)$ methods, and the protein concentration was monitored as $A_{280}(\ldots)$.

was maximal after $3 \mathrm{~d}\left(304 \mathrm{U} \mathrm{ml}^{-1}\right)$. After the final chromatography of the crude enzyme on Sephacryl S200 , a single peak of isoamylase activity was detected when fractions were assayed by both the dinitrosalycilic acid and iodine coloration methods (Fig. 1). The degree of purification and total recovery are summarized in Table 1. Approximately 166-fold purification was achieved, with an overall yield of $6.8 \%$ and a specific activity of $469 \mathrm{U}(\mathrm{mg} \text { protein })^{-1}$. When the iodine coloration method was used, the purified enzyme had a specific activity of $39.4 \mathrm{U}$ (mg protein $)^{-1}$. The characterization of the isoamylase was performed exclusively with the final preparation.

\section{Homogeneity, absorption spectrum, molecular mass and isoelectric point}

The purified enzyme preparation was tested for purity by nondenaturing PAGE and SDS-PAGE, which both gave

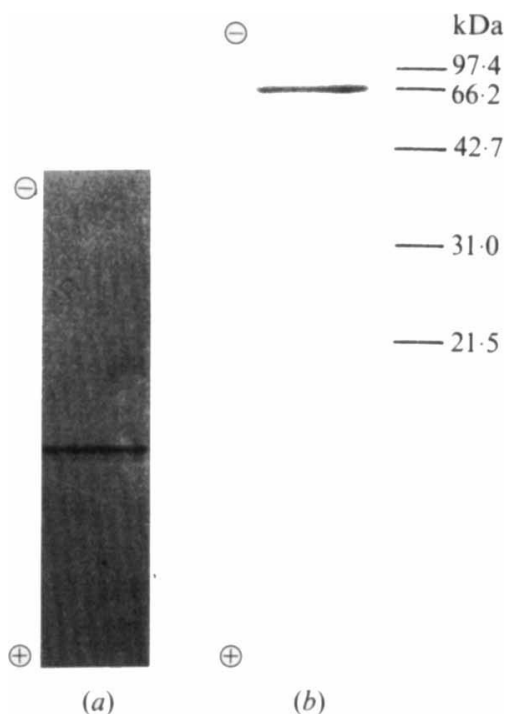

Fig. 2. Nondenaturing PAGE $(a)$ and SDS-PAGE $(b)$ of the purified isoamylase from Bacillus sp. KSM-3309. PAGE was done on a $7.5 \%$ $(\mathrm{w} / \mathrm{v})$ polyacrylamide slab gel ( $1 \mathrm{~mm}$ thickness) with $5 \mathrm{~mm}-\mathrm{Tris} / 38 \mathrm{~mm}$ glycine/ $\mathrm{NaOH}$ buffer (pH 8.5) as the running buffer. SDS-PAGE was done on a $15 \%(\mathrm{w} / \mathrm{v})$ polyacrylamide slab gel with $25 \mathrm{mM}$-Tris/glycine buffer (pH 8.3) containing 0.1\% (w/v) SDS as the running buffer, after the enzyme had been heated at $95^{\circ} \mathrm{C}$ for $5 \mathrm{~min}$ in $62.5 \mathrm{~mm}$-Tris $/ \mathrm{HCl}$ buffer (pH 6.8) containing $20 \%$ (w/v) SDS, $10 \%$ (v/v) glycerol and $5 \%(\mathrm{v} / \mathrm{v}) 2$-mercaptoethanol. Approximately $7 \mu \mathrm{g}$ of the purified enzyme was used for electrophoresis in each case. The bands of protein were visualized by silver staining (Oakley et al., 1980).

a single band of protein when proteins were visualized by silver staining (Fig. 2). The purified enzyme had an absorption maximum at $280 \mathrm{~nm}$ due to the presence of a simple protein, with an absorption coefficient $\left(A_{1 \mathrm{~cm}}^{1 \%}\right.$ at $280 \mathrm{~nm}$ ) of $11 \cdot 8$. The molecular mass of the enzyme was estimated to be $65 \mathrm{kDa}$ by gel filtration using Sephacryl S-200. SDS-PAGE gave the same molecular mass of $65 \mathrm{kDa}$ for subunits of the enzyme (Fig. 2). These results indicate that the purified enzyme has a monomeric structure. The isoelectric point of the enzyme was estimated to be $\mathrm{pH} 4 \cdot 2$ by isoelectric focusing (see Methods).

Table 1. Purification of the isoamylase from Bacillus sp. KSM-3309

\begin{tabular}{lccccc}
\hline \hline $\begin{array}{c}\text { Purification } \\
\text { step }\end{array}$ & $\begin{array}{c}\text { Total } \\
\text { protein } \\
(\mathrm{mg})\end{array}$ & $\begin{array}{c}\text { Total } \\
\text { activity } \\
(\mathrm{U})\end{array}$ & $\begin{array}{c}\text { Specific } \\
\text { activity } \\
\left(\mathrm{U} \mathrm{mg}^{-1}\right)\end{array}$ & $\begin{array}{c}\text { Yield } \\
(\%)\end{array}$ & $\begin{array}{c}\text { Purification } \\
(\text {-fold })\end{array}$ \\
\hline Cell-free culture & 390 & 1100 & $2 \cdot 82$ & 100 & $1 \cdot 0$ \\
Ammonium sulphate & $25 \cdot 3$ & 811 & $32 \cdot 1$ & 74 & $11 \cdot 4$ \\
DE52-cellulose & $13 \cdot 6$ & 597 & $43 \cdot 9$ & 54 & $15 \cdot 6$ \\
DEAE-Bio-Gel A & $1 \cdot 22$ & 205 & 168 & 19 & $59 \cdot 6$ \\
Sephacryl S-200 & $0 \cdot 16$ & 75 & 469 & $6 \cdot 8$ & 166 \\
\hline \hline
\end{tabular}


Table 2. Substrate specificity of the isoamylase

Assays were performed at $40^{\circ} \mathrm{C}$ in $40 \mathrm{~mm}$-glycine/ $\mathrm{NaCl} / \mathrm{NaOH}$ buffer ( $\mathrm{pH} 9.0$ ) with $0.17 \mathrm{~g}$ of enzyme under the standard reaction conditions.

\begin{tabular}{lcc}
\hline \multicolumn{1}{c}{$\begin{array}{c}\text { Substrate } \\
(0 \cdot 25 \%, \mathrm{w} / \mathrm{v})\end{array}$} & $\begin{array}{c}\text { Isoamylase } \\
\text { activity } \\
\left(\mathrm{U} \mathrm{mg} \mathrm{m}^{-1}\right)\end{array}$ & $\begin{array}{c}\text { Relative } \\
\text { activity } \\
(\%)\end{array}$ \\
\hline Glycogen (oyster) & 470 & 100 \\
Glycogen (bovine muscle) & 522 & 111 \\
Glycogen (rabbit liver) & 369 & 78.6 \\
Amylopectin (potato) & 555 & 118 \\
Amylopectin (corn) & 667 & 142 \\
Pulullan & $7 \cdot 4$ & 1.57 \\
Amylose (potato, DP $=17)$ & 0 & 0 \\
Maltose* & 0 & 0 \\
\hline \hline
\end{tabular}

* Glucose generated from maltose $(10 \mathrm{~mm})$ was quantified by the glucose/peroxidase procedure (Glucose C-Test; Wako Pure Chemical).

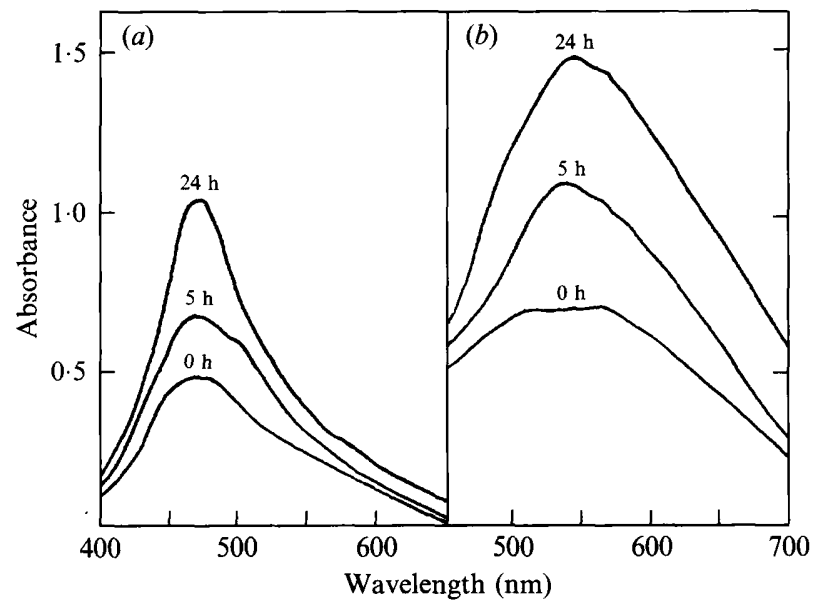

Fig. 3. Changes in the absorption spectrum of the iodine-staining solution when glycogen $(a)$ and amylopectin $(b)$ were treated with the alkaline isoamylase. Oyster glycogen and potato amylopectin $(50 \mathrm{mg}$ each) were incubated at $40{ }^{\circ} \mathrm{C}$ with purified enzyme $(43 \mathrm{mU})$ in a final volume of $5.0 \mathrm{ml}$ in $40 \mathrm{~mm}$-Tris $/ \mathrm{HCl}$ buffer $(\mathrm{pH} 8.0)$. At the times indicated on the spectra, $1.0 \mathrm{ml}$ aliquots were withdrawn and mixed with $4 \mathrm{ml}$ iodine solution $\left(0.002 \% \mathrm{I}_{2} / 0.02 \% \mathrm{KI}\right)$. The samples were diluted to $8.0 \mathrm{ml}$ with deionized water and used for determination of the absorption spectra of the iodine complex.

\section{Substrate specificity}

The purified enzyme preparation was examined for its ability to hydrolyse various carbohydrates at $40^{\circ} \mathrm{C}$ and at $\mathrm{pH} 9.0$ in $40 \mathrm{~mm}$-glycine/ $\mathrm{NaCl} / \mathrm{NaOH}$ buffer (Table 2 ). Of the carbohydrate substrates tested, glycogens (from oyster, rabbit liver and bovine muscle) and amylopectins (from potato and corn) were efficiently hydrolysed at similar rates. In the products of hydrolysis of these substrates, glucose and maltodextrins (maltose to maltohexaose) were not detectable after paper chromatography of the hydrolysates (for details of the chromatographic procedure, see Methods). The enzyme had an apparent $K_{\mathrm{m}}$ value of $0.59 \mathrm{mg} \mathrm{ml}^{-1}$ for potato amylopectin, with a $V_{\max }$ of $588 \mathrm{U}(\mathrm{mg} \text { protein })^{-1}$; and a $K_{\mathrm{m}}$ of $0.45 \mathrm{mg} \mathrm{ml}^{-1}$ for oyster glycogen, with a $V_{\max }$ of $645 \mathrm{U}$ (mg protein $)^{-1}$. Pullulan $(\alpha-1 \cdot 6$-linkage), amylose $(\alpha-1,4-$ linkage), and maltose were practically unaffected by the enzyme.

Fig. 3 shows the changes in absorption spectra of the iodine-staining solution for products of potato amylopectin and oyster glycogen generated during their treatment with the enzyme. With both substrates, the absorbance increased and the maximum wavelength of absorption shifted to a longer wavelength (from 530 to $550 \mathrm{~nm}$ ) as the enzyme reaction proceeded. These results suggest that this enzyme can hydrolyse the 1,6- $\alpha$ glucosidic linkages of branched $\alpha$-D-glucans and that it differs from pullulanases (EC 3.2.1.41), which can hydrolyse pullulan to generate oligosaccharides (Bender \& Wallenfels, 1961; Walker, 1968; Nakamura et al., 1987; Ara et al., 1992). It seems appropriate to refer to the enzyme described in this report as an isoamylase.

\section{Effects of $p H$ on the activity and stability of the enzyme}

The effect of $\mathrm{pH}$ on the activity of the purified isoamylase was determined at $40^{\circ} \mathrm{C}$ in various buffers between pH 4.0 and pH 12.0 (Fig. 4). Maximum activity toward oyster glycogen was observed at around $\mathrm{pH} 9.0$ in $40 \mathrm{~mm}$-glycine $/ \mathrm{NaCl} / \mathrm{NaOH}$ buffer. The enzyme was active between $\mathrm{pH} 5 \cdot 0$ and $\mathrm{pH} 11 \cdot 5$, with more than $65 \%$ of the maximum activity being detectable at $\mathrm{pH} 10$. To determine the stability of the enzyme activity to changes in $\mathrm{pH}$, the isoamylase was preincubated overnight at $4{ }^{\circ} \mathrm{C}$ in various buffers and then assayed at $40^{\circ} \mathrm{C}$ and pH 9.0 in $0.1 \mathrm{M}$-glycine $/ \mathrm{NaCl} / \mathrm{NaOH}$ buffer. The enzyme activity remained unchanged during incubations in buffers at $\mathrm{pH} 7.5$ to $\mathrm{pH} 9 \cdot 5$ (Fig. 4). More than $50 \%$ of the original activity was detectable after incubation in buffers at $\mathrm{pH}$ values between 6.6 and 10.5 .

\section{Effects of temperature on the activity and stability of the enzyme}

The activity of the alkaline isoamylase with glycogen as substrate was determined at various temperatures in 40 mm-glycine $/ \mathrm{NaCl} / \mathrm{NaOH}$ buffer ( $\mathrm{pH} 9 \cdot 0$ ). Maximum activity with oyster glycogen as substrate was detected at around $55^{\circ} \mathrm{C}$. At temperatures below $30^{\circ} \mathrm{C}$ and above $65^{\circ} \mathrm{C}$ the enzyme was almost inactive. The activity of the enzyme was also examined after it had been heated at various temperatures for $30 \mathrm{~min}$ in $40 \mathrm{~mm}$-glycine/ $\mathrm{NaCl}$ / $\mathrm{NaOH}$ buffer (pH 9.0). The enzyme was stable up to $40{ }^{\circ} \mathrm{C}$. Above this temperature, the stability of the enzyme gradually decreased, with less than $5 \%$ of the 


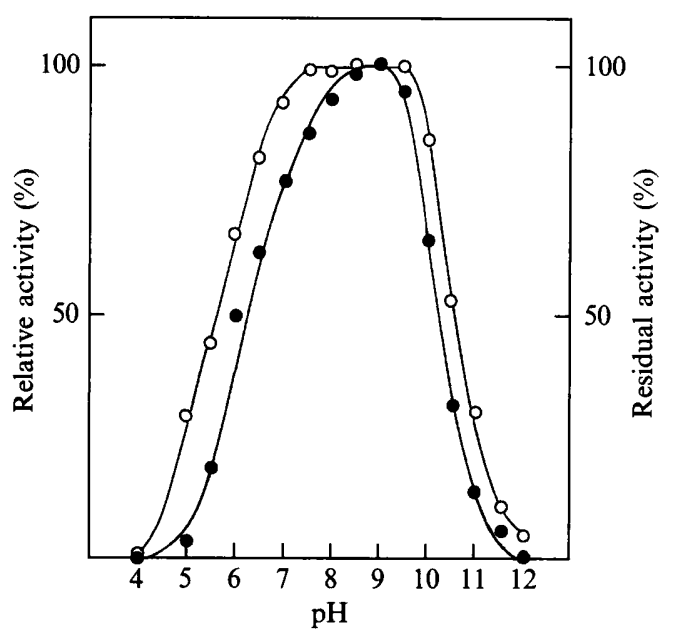

Fig. 4. Effects of $\mathrm{pH}$ on the activity and stability of the purified

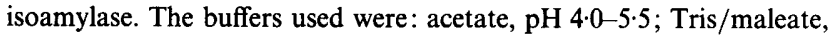
pH 5.5-8.5; glycine/ $\mathrm{NaCl} / \mathrm{NaOH}, \mathrm{pH} 8.5-10.5$; borate, $\mathrm{pH} 10.5-12.0$. The isoamylase activity (O) was measured at $40^{\circ} \mathrm{C}$ in the indicated buffers at $40 \mathrm{~mm}$, at various $\mathrm{pH}$ values, with $0.17 \mu \mathrm{g}$ enzyme and oyster glycogen as substrate. Enzyme activity at pH 9.0 in $40 \mathrm{~mm}$-glycine/ $\mathrm{NaCl} / \mathrm{NaOH}$ buffer was taken as $100 \%$. The stability of the enzyme (O) was examined in buffers of various $\mathrm{pH}$. The enzyme $(1.7 \mu \mathrm{g})$ was incubated at the indicated $\mathrm{pH}$ in $1.0 \mathrm{ml} 10 \mathrm{~mm}$-buffer overnight at $4{ }^{\circ} \mathrm{C}$, then aliquots of $0.1 \mathrm{ml}$ were withdrawn and the residual isoamylase activity was measured at $40^{\circ} \mathrm{C}$ and $\mathrm{pH} 9.0$ in $0.1 \mathrm{M}$-glycine/ $\mathrm{NaCl} /$ $\mathrm{NaOH}$ buffer. The values shown are the percentages of the original activity.

original activity remaining after $30 \mathrm{~min}$ incubation at $60^{\circ} \mathrm{C}$ (data not shown).

\section{Effects of chemical reagents}

The activity of alkaline isoamylase, with oyster glycogen as substrate, was examined after the enzyme had been incubated with various chemical reagents (each $1 \mathrm{mM}$ ) in $10 \mathrm{mM}$-glycine $/ \mathrm{NaCl} / \mathrm{NaOH}$ buffer $(\mathrm{pH} 8.0)$ at $40{ }^{\circ} \mathrm{C}$ for $15 \mathrm{~min}$. An aliquot $(0 \cdot 1 \mathrm{ml})$ was then used to assay the residual isoamylase activity in $0.1 \mathrm{M}$-glycine buffer. The enzyme was not significantly affected by the following cations: $\mathrm{Na}^{+}, \mathrm{K}^{+}, \mathrm{Mg}^{2+}, \mathrm{Ca}^{2+}, \mathrm{Mn}^{2+}, \mathrm{Ni}^{2+}, \mathrm{Co}^{2+}, \mathrm{Cu}^{2+}$, $\mathrm{Cd}^{2+}, \mathrm{Ba}^{2+}, \mathrm{Fe}^{2+}, \mathrm{Fe}^{3+}$ and $\mathrm{Al}^{3+}$. The notable exception was $\mathrm{Hg}^{2+}(52 \%$ inhibition). However, the thiol inhibitors $N$-ethylmaleimide (at $20^{\circ} \mathrm{C}$ ), monoiodoacetate (at pH 5.0 in $10 \mathrm{~mm}$-acetate buffer) and 4-chloromercuribenzoate (at pH 5.0 in $10 \mathrm{~mm}$-acetate buffer), either had no effect or caused very low levels of inhibition. $N$ Bromosuccinimide $(10 \mu \mathrm{M})$ abolished enzyme activity almost completely, after incubation of the enzyme at $4{ }^{\circ} \mathrm{C}$ and $\mathrm{pH} 5.0$ in $10 \mathrm{~mm}$-acetate buffer with this compound for $15 \mathrm{~min}$. EDTA (10 mM), phenylmethanesulphonyl fluoride (1 mM), $\alpha$-cyclodextrin $(10 \mathrm{~mm})$ and $\beta$ cyclodextrin $(10 \mathrm{~mm})$ were not inhibitory under the standard assay conditions.

\section{Discussion}

Members of the genus Bacillus produce various kinds of extracellular enzyme of industrial importance, including amylases, proteinases, endoglucanases and pectinases.

In the present study, we isolated an obligately aerobic and alkalophilic strain of Bacillus, KSM-3309, which produces an isoamylase with a $\mathrm{pH}$ optimum of $9 \cdot 0$. Under the alkaline reaction conditions used in this study, this enzyme efficiently hydrolysed amylopectin and glycogen, but it had no appreciable activity against pullulan or amylose. The colour generated by iodinestaining of digests of amylopectin and glycogen changed to blue, with a shift in the absorption maximum from $530 \mathrm{~nm}$ to $550 \mathrm{~nm}$, and the absorption also increased significantly (see Fig. 3 ). These results suggest that the action of the alkaline enzyme on amylopectin and glycogen resulted in specific cleavage of $\alpha$-1,6-glucosidic inter-chain linkages, producing essentially linear chains.

The isoamylase from Bacillus sp. KSM-3309 shows activity and stability at the highest $\mathrm{pH}$ reported thus far for isoamylases from micro-organisms and higher plants. Acid and neutral isoamylases have been reported from Pseudomonas amyloderamosa (Yokobayashi et al., 1970), Cytophaga sp. (Gunja-Smith et al., 1970a). Bacillus amyloliquefaciens (Urlaub \& Wober, 1975), E. coli (Jeanningros et al., 1975), Flavobacterium sp. (Sato \& Park, 1980), the yeast Lipomyces kononenkoae (SpencerMartins, 1982) and potato tubers (Solanum tuberosum L.; Ishizuka et al., 1983), the maximum $\mathrm{pH}$ for activity of these enzymes being $3 \cdot 5,5 \cdot 5,5 \cdot 0,5 \cdot 6-6 \cdot 4,6 \cdot 3,5 \cdot 6$ and $5 \cdot 5-6 \cdot 0$, respectively.

The alkaline isoamylase from Bacillus sp. KSM-3309 was inhibited by $\mathrm{Hg}^{2+}$ ions but not by the thiol inhibitors iodoacetate, 4-chloromercuribenzoate and $\mathrm{N}$-ethylmaleimide. Thus, the inhibition by $\mathrm{Hg}^{2+}$ ions is unlikely to be due to interactions with cysteine residues, but it could involve interactions with tryptophan residue(s). The isoamylase activity was completely abolished by a low concentration $(10 \mu \mathrm{M})$ of $N$-bromosuccinimide, which oxidizes tryptophan residues (Eriksson \& Pettersson, 1968). It has been suggested that a histidine residue may be important for the activity of an isoamylase from Pseudomonas (Kitagawa et al., 1975). Our isoamylase was not inhibited by $\beta$-cyclodextrin, as was also true for an isoamylase from $L$. kononenkoae (Spencer-Martins, 1982). Marshall (1973) showed that cyclodextrins do not inhibit the isoamylase activity of Cytophaga but strongly inhibit the pullulanase activities of Aerobacter and sweet potato. He suggested that an examination of sensitivity toward cyclodextrins might provide a simple method for differentiating isoamylases from pullulanases. Our data tend to support his suggestion. 
Amemura et al. (1988) and Tognoni et al. (1989) cloned and sequenced the genes for the isoamylases from $P$. amyloderamosa SB-15, which had been isolated by Harada et al. (1968), and Pseudomonas sp SMP1, respectively. They found that the deduced amino acid sequences of isoamylases from strains SB-15 and SMP1 both showed considerable homology of those of $\alpha$ amylases, pullulanases and a cyclodextrin glucanotransferase (EC 2.4.1.19). Homology was especially conspicuous in the regions that included the proposed catalytic and substrate-binding sites. The sequences of the two pseudomonad enzymes also have several regions that are similar to regions in a neopullulanase isolated from the alkalophilic Bacillus sp. KSM-1876 (Igarashi et $a l ., 1992)$. It is of interest that the isoamylases of strains SB-15 and SMP1 have optimum $\mathrm{pH}$ values for activity between 3 and 4 , while the optimum $\mathrm{pH}$ is 9.0 for the enzyme from Bacillus sp. KSM-3309. The deduced amino acid sequence of this alkaline enzyme may be helpful in identifying protein motifs that determine the $\mathrm{pH}$ optima for isoamylases of microbial origin. Current work is focussing on the cloning and sequencing of the alkaline isoamylase gene from Bacillus sp. KSM-3309.

\section{References}

Akai, H., Yokobayashi, K., Misaki, A. \& Harada, Y. (1971). Complete hydrolysis of branching linkages in glycogen by pseudomonas isoamylase: distribution of linear chains. Biochimica et Biophysica Acta 237, 422-429.

Amemura, A., Chakraborty, R., Fuitta, M., Noumi, T. \& Futal, M. (1988). Cloning and nucleotide sequence of the isomylase gene from Pseudomonas amyloderamosa SB-15. Journal of Biological Chemistry 263, 9271-9275.

Ara, K., Igarashi, K., Saeki, K., Kawal, S. \& Ito, S. (1992). Purification and some properties of an alkaline pullulanase from alkalophilic Bacillus sp. KSM-1876. Bioscience, Biotechnology, and Biochemistry 56, 62-65.

BENDER, H. \& W ALlENFEls, K. (1961) Untersuchungen an Pullulan. II. Spezifischer Abbau durch ein bakterielles Enzym. Biochemische Zeitschrift 334, 79-95.

BRADFORD, M. M. (1976). A rapid and sensitive method for the quantitation of microgram quantities of protein utilizing the principle of protein-dye binding. Analytical Biochemistry 72, 248-254.

Claus, D. \& Berkeley, R. C. W. (1986). Genus Bacillus. In Bergey's Manual of Systematic Bacteriology, vol. 2, pp. 1105-1139. Edited by P. H. A. Sneath, N. S. Mair, M. E. Sharpe \& J. G. Holt, Baltimore: Williams \& Wilkins.

Eriksson, K.-E. \& Pettersson, G. (1968). Studies on cellulolytic enzymes. V. Some structural properties of the cellulase from Penicillium notatum. Archives of Biochemistry and Biophysics 124, 160-166.

Gordon, R. E., Haynes, W. C. \& Pang, C. H. (1973). The Genus Bacillus. Washington, DC: US Department of Agriculture.

Gunja, Z. H., Manners, D. J. \& Maung, K. (1961). Studies on carbohydrate-metabolizing enzymes. VII. Yeast isoamylase. Biochemical Journal 81, 392-398.

Gunja-Smith, Z., Marshall, J. J., Mercier, C., Smith, E. E. \& WHELAN, W. J. (1970a). A glycogen-debranching enzyme from Cytophage. FEBS Letters 12, 96-100.

Gunja-Smith, Z., Marshall, J. J., Mercier, C., Smith, E. E. \& WHELAN, W. J. (1970 b). A reversion of the Mayer-Bernfeld model of glycogen and amylopectin. FEBS Letters 12, 101-104.
Harada, T., Yokobayashi, K. \& Misaki, A. (1968). Formation of isoamylase by Pseudomonas. Applied Microbiology 16, 1439-1444.

Harada, T., Misaki, A., Akai, K., Yokobayashi, K. \& Sugimoto, K. (1972). Characterization of Pseudomonas isoamylase by its actions on amylopectin and glycogen: comparison with Aerobacter pullulanase. Biochimica et Biophysica Acta 268, 497-505.

HizUKuRI, S., Kaneno, T. \& TAKeda, I. (1983). Measurement of the chain length of amylopectin and its relevance to the origin of crystalline polymorphism of starch granules. Biochimica et Biophysica Acta 760, 188-191.

Igarashi, K., Ara, K., Saeki, K., Ozaki, K., Kawai, S. \& Ito, S. (1992). Nucleotide sequence of the gene that encodes a neopullulanase from an alkalophilic Bacillus. Bioscience, Biotechnology, and Biochemistry 56, 514-516.

Ishizuka, Y., Taniguchi, H., Maruyama, Y. \& Nakamura, M. (1983). Debranching enzymes of potato tubers (Solanum tuberosum L.). I. Purification and some properties of potato isoamylase. Agricultural and Biological Chemistry 47, 771-779.

Jeanningros, R., Creuzet, N., Frixon, C. \& Cattaneo, J. (1975). A debranching enzyme in Escherichia coli. Biochemical Society Transactions 3, 336-337.

Kitagawa, H., Amemura, A. \& Harada, T. (1975). Studies on the inhibition and molecular properties of crystalline Pseuodomonas isoamylase. Agricultural and Biological Chemistry 39, 989-994.

MARSHALL, J. J. (1973). Inhibition of pullulanase by Schardinger dextrins. FEBS Letters 37, 269-273.

Maruo, B. \& Kobayashi, T. (1951). Enzymic scission of the branch links in amylopectin. Nature, London 167, 606-607.

Miller, G. L., Blum, R., Glennon, W. E. \& Burton, A. L. (1960) Measurement of carboxymethylcellulase activity. Analytical Biochemistry 2, 127-132.

Nakamura, N., Sashihara, N., Nagayama, H. \& Horikoshi, K. (1987). Production of a thermostable pullulanase by Thermus sp. Journal of the Japanese Society of Starch Science 34, 38-44.

Norman, B. E. (1982). A novel debranching enzyme for application in the glucose syrup industry. Starch/Stärke 34, 340-346.

OAKLEY, B. R., KIRSCH, D. R. \& MORRIS, N. R. (1980). A simplified ultrasensitive silver stain for detecting proteins in polyacrylamide gels. Analytical Biochemistry 105, 361-363.

OKoshi, H., Ozaki, K., Shikata, S., Oshino, K., Kawai, S. \& Ito, S. (1990). Purification and characterization of multiple caroxymethylcellulases from Bacillus sp. KSM-522. Agricultural and Biological Chemistry 54, 83-89.

SATO, H. H. \& PARK, Y. K. (1980). Purification and characterization of extracellular isoamylase from Flavobacterium sp. Starch/Stärke 32, $132-136$.

SPENCER-MARTINS, I. (1982). Extracellular isoamylase produced by the yeast Lipomyces kononenkoae. Applied and Environmental Microbiology 44, 1253-1257.

StOminsKa, L. \& MACZYNSKI, M. (1985). Studies on the application of pullulanase in starch saccharification process. Starch/Stärke 37, 386-390.

Tognoni, A., Carrera, P., Galli, G., Lucchese, G., Camerini, B. \& GRANDI, G. (1989). Cloning and nucleotide sequence of the isoamylase gene from a strain of Pseudomonas sp. Journal of General Microbiology 135, 37-45.

Trevelyan, W. E., Procter, D. P. \& Harrison, J. S. (1950). Detection of sugars on paper chromatograms. Nature, London 166, 444-445.

URLAUB, H. \& WOBER, G. (1975). Identification of isoamylase, a glycogen-debranching enzyme, from Bacillus amyloliquefaciens. FEBS Letters 57, 1-4.

WALKER, G. J. (1968). Metabolism of the reserve polysaccharide of Streptococcus mitis. Biochemical Journal 108, 33-40.

WrigLEY, C. W. (1971). Gel electrofocusing. Methods in Enzymology 22, 559-564.

YokOBayASHI, K., Misaki, A. \& HaRADa, T. (1970). Purification and properties of pseudomonas isoamylase. Biochimica et Biophysica Acta 212, 458-469.

Yoshimatsu, T., Ozaki, K., Shikata, S., Ohta, Y., Koike, K., KawaI, S. \& ITO, S. (1990). Purification and characterization of alkaline endo-1,4- $\beta$-glucanases from alkalophilic Bacillus sp. KSM-635. Journal of General Microbiology 136, 1973-1979. 